\title{
The Impact of Export and Foreign Direct Investments on Macedonian GDP Growth - Empirical Analysis
}

\author{
Jeton Shaqiri, PhD \\ International University of Struga, R.Macedonia
}

doi: 10.19044/esj.2017.v13n25p276 URL:http://dx.doi.org/10.19044/esj.2017.v13n25p276

\begin{abstract}
In this paper in chronological order is analyzed the Macedonia's economic development in general, considering that the country has a liberal trade regime which is characterized by simplicity and neutrality. R. of Macedonia should utilize this trade regime in direction of creating policies and conditions for promoting the private sector development and its possibilities for export that will contribute for greater macroeconomic development.

The paper will have a detailed look to the overall economic development and the GDP growth, the components and the main factors influencing this growth, techniques and approaches of assessment of the economic system and its development. It will also analyze the role of exports and the foreign direct investments in Macedonian GDP growth. Numerous theoretical researches related to the role of exports and FDI in GDP growth, have shown a positive relationship between them.

The data used in this paper were provided by the Statistical Office of Macedonia and the Macedonian Customs in different periods, while for the empirical analysis I have included the period from 2014-2015.

Within the empirical analysis is applied a model of multiple linear regression, where is defined the dependent variable "GDP growth" as well as the independent variables: the growth of FDI and the growth of export.
\end{abstract}

Keywords: Gross domestic product, Export, Foreign Direct Investments, Economic Development, Trade Policy

\section{Literature Review}

Most developing countries consider FDI as a vital source for development. However, the economic effects of FDI are very difficult to measure accurately given that growth depends on many factors whose effects are difficult to disentangle, and given that FDI itself affects several of these factors. Therefore, the analysis of the FDI effects resorts to one of two 
general approaches. The first is econometric analysis of the relationships between FDI flows and various measures of economic performance, and the second is a qualitative analysis of particular aspects of FDI contribution.

The econometric analysis of FDI and development is of long standing, but its conclusions sometimes remain unclear. Some analyses show a positive impact while others remain agnostic. On the other hand, the qualitative analysis of FDI is more appealing and practical. The premise is that FDI offer host countries a mixture of positive and negative effects. The challenge is to disentangle these effects, taking measures to maximize the first ones and minimize the others. A compilation of recent literature on theory and measurement issues of FDI, structural issues related to the impact of FDI, as well as some analytical and policy issues can be found in Bora (2002). In-depth analysis of selected topics related to FDI can be found in different UNCTAD publications. Also, a list of World Bank's papers and case studies deal with the following general topics: FDI impact on growth, trade flows and employment; skills and technology diffusion via FDI; linkages with domestic companies, etc. The paper by Benacek, Gronicki, Holland, Sass (2000) is a methodological paper that points to the benefits and pitfalls of surveys and econometric analysis as two main sources of information. The authors consider how each of these two sources can contribute to the field of research, whether they give us complementary or contradictory information and how this information can be best exploited. They conclude that the findings of econometric studies tend to support survey results. Jevcak, Setzer, Suardi (2010) analyzed FDI inflows in 10 new EU member countries (from the $2004 \mathrm{EU}$ enlargement), taking into account the specific features of the emerging economies and also pointing out the importance of the FDI structure. The capital inflows to this group of countries were driven by the country specific factors and also by the global driving forces. One of the conclusions of this paper is that stronger growth and higher interest rates tend to be associated with the larger capital inflows. Anyway, the authors found that a large part of foreign capital in the analyzed countries was directed towards the non - tradable sector, implying lower contribution to productivity growth and export potential. In addition, a high dependence on large foreign capital inflows could be a source of potential vulnerability of the economy in case of a change in the environment and risk perception (evident during the recent crisis). This paper should contribute to both general approaches - the econometric analysis of the relationships between FDI inflows and GDP growth and export performances, and the qualitative analysis of various aspects of FDI's contribution to the performances of the Macedonian economy, therefore being complementary to the studies on FDI in the transition economies. A specific contribution of this research is the structural dimension of the analysis. 


\section{Significant economic developments in R. Macedonia}

On the stagnation of economic development as well as on the export sector in Macedonia have influenced many factors such as the inheritance of a not so stable industry and the lack of regional initiatives that would support trade liberalization and this is the exactly due to the unsolved political and economic status.

Attracting Foreign Direct Investments is one of the main goals of Macedonian government, which develops different strategies and policies for stimulating and attracting foreign investors. But, a lot of other factors have direct impact on the FDI inflows in Macedonia, such as the economic stability, the strengthening of law and legislative institutions, the infrastructure and as well as providing a more stable business climate.

The economic growth includes creation of quality innovative policies for technology development that will increase productivity in all economic sectors, and will contribute for increase of GDP. The functioning of the capital markets as well as the opening of new markets through the trade exchange, also have positive effect on the overall economic growth.

The economic growth is an indicator for successful management of the economic recourses' performance that identifies the economy of one country.

If we have an economic growth it means a higher level of per capita income, which means more goods and services consumed in the society as a whole.

Table 1:Gross domestic product

\begin{tabular}{|c|c|c|c|}
\hline & 2013 & 2014 & 2015 \\
\hline Real growth in \% * & 2,9 & 3,5 & 3,7 \\
\hline
\end{tabular}

Source: Central Bank of RM

Data in Table 1 shows that the real GDP growth rate for 2013 was 2.9 percent and the real growth for the year 2014 is 3.7 percent, real GDP growth for 2015 is 3.7 percent. From this table it can be noticed an oscillation of GDP growth through the years. The indicators that have contributed to this oscillation will be mentioned below with a particular emphasis on the impact of exports and FDI flows on the economic development.

\section{The main barriers in the development of the export sector in Macedonia}

In the absence of a sustainable development and not enough stimulative economic policies for the development of manufacturing businesses in Macedonia, under the influence even of the trade liberalization, are displayed the following impacts: difficulties in the transformation of 
business structures, low level of manufacturing businesses and products, the symbolic participation of export businesses in trade exchange, non-favorable business environment for new business initiatives, difficulties in building the competitiveness of domestic businesses for competing on regional and foreign markets.

Also, another group of problems affects the export activities in Macedonia, problems that are deep rooted in the Macedonian economy and politics, some of them inherited and some associated with the long lasting process of transition.

First one, the unsolved political status places Macedonia in an unequal position with its neighbors in the context of regional initiatives. Second, tax policy does not favor domestic production and uniform tariff rate discourages the development of manufacturing businesses in Macedonia. Third, firms in Macedonia face internal problems, such as the lack of capital, lack of experience in foreign markets, lack of expertise as well as marketing and poor promotional activities.

Fourth, entrepreneurs in Macedonia face barriers that hinder their normal functioning including limited credit access and high interest rates, poor infrastructure, lack of information, weak institutional support and other administrative barriers.

\section{The impact of domestic factors on export}

Many studies, whether they are theoretical or empirical, focus mainly on managerial development level and limited resources as the main internal obstacles in a firm's activity. Specifically, they concentrate on the problems arising from the organizational structure, the educational level and training of the staff, the determination and managerial approach to export, and managerial experience.

Other domestic factors are the differences in language and culture, customs regulations, national legislation, sources of information, the way markets operate, the level and nature of competition, difficulties in enforcing contracts, etc. Finding information on foreign markets is essential. The belief that information ease the decision making process and reduce uncertainty in business has led to the creation of a scientific consensus that the growth and survival of businesses today depends entirely on strategies for managing and processing information (Hart and Tzokas, 1999).

\section{The impact of external factors on export}

According to Hare (2000) these barriers are mainly related to the complete dysfunction of the banking system, especially the secure management of the international transactions, the lack of guarantee schemes for export credits and other forms of export promotion, poor insurance of 
transactions and other services related to export activities. Moreover, these institutional barriers also take the form of long waits at the border, which at the same time are accompanied by huge corruption in order to accelerate the movement of goods. None of the above has anything to do with economic policy, but it is associated mostly with the ability and willingness of countries to implement the law.

\section{The role of foreign direct investment in the GDP growth}

Foreign Direct Investment is a form of investment that earns interest in the company, which operates outside the country of the investor. Factors such as economic growth, de-regulation, liberal investment rules and operational flexibility are factors that affect the growth of the FDI's flows. It is established a positive correlation between investments and the growth of GDP of the host country, due to the increased export opportunities and stimulating positive effects on local businesses and improving their competitiveness.

R. of Macedonia would have to follow an active policy that will improve the promotion of cooperation opportunities with foreign investors, increase the competitivness on the investment market and increase the acqusition capability for establishing partnership and joint investments.

2. The empirical analysis of the exports and FDI flows impact on the GDP growth

Factors affecting the country`s GDP growth are numerous; some of them were mentioned in the literature review.

The conditions and factors that influence / support economic sustainability are the following:

- Capital / Human Resources

- Natural wealth

- The accumulation of capital and investment resources

- Institutional capacities

- Macroeconomic stability and economic policies implementation

- The quality of public infrastructure

Besides these factors we came to the conclusion that the development of the export sector and foreign direct investments has a key role in GDP growth which has been analyzed in details.

In the case of Macedonia, the export sector had a particular impact in the GDP growth and this was also demonstrated by this research, which shows that year after year, along with the export growth we also have an increased GDP and the opposite. In the empirical analysis we could see the effects of each independent variable, and in our case we have taken the export and the FDI flows and their effects on GDP growth. 


\section{Data and Methodology}

For this research, the analysis method is mostly used to analyze documentation that refers to specific literature from the macroeconomic field in general, as well as the factors that influence the macroeconomic development of the country. Also, the comparative method is used in order to measure the ratio between the exports, FDI flows and GDP growth in Macedonia in different time periods, as well as many observations that deal with the analysis of variables that affects in a positive or negative way. The data used in the empirical analysis is provided by the Central Bank of Macedonia, the Ministry of Economy and the Agency for foreign investments.

\section{Descriptive statistics}

Within the descriptive statistics have been analyzed the activities of the dependent variable, the "GDP General Gross Domestic Product," and the independent or explanatory variables which are included in the econometric model. The following table shows an overview of data used in the analysis, such as the number of observations, minimum, maximum, average and standard deviation.

Table 2: Descriptive statistics for the variables in the applied model

\begin{tabular}{|c|c|c|c|c|c|c|}
\hline \multicolumn{7}{|c|}{ Descriptive Statistics } \\
\hline & $\mathrm{N}$ & Min & Max & Average & $\begin{array}{c}\text { Standard } \\
\text { deviation }\end{array}$ & Variance \\
\hline RRGDP in \% & 12 & .019 & .131 & .05774 & .032487 & .001 \\
\hline RRIJD/RRGDP & 12 & -.460 & 1.763 & .39938 & .747631 & .559 \\
\hline RREXP/GDP & 12 & -.567 & .968 & .20415 & .413068 & .171 \\
\hline Valid N (list) & 12 & & & & & \\
\hline
\end{tabular}

Source: Author's calculation

Data in Table 2 show that the growth of GDP has a positive average rate of 3,57\%, while the minimum value achieved is $1.9 \%$ and the maximum is $1,31 \%$ as well as in a standard deviation with 3,24 percent. GDP has the maximum average rate of $3.99 \%$; the minimum is negative indicating that every drop of foreign direct investments will negatively impact on the GDP growth.

\section{Correlation Analysis}

Table number 3, shows the matrix of correlation which summarizes the correlations between all variables (Buyuksavarci and Abdioglu, 2011). Based on the correlation matrix it can be seen that we have a positive correlation between the growth of GDP and export growth. Also, we have a negative correlation in the relationship between the growth of GDP and the FDI growth. 
Table 3.- Correlation Analysis -Pearson Correlation

\begin{tabular}{|c|c|c|c|c|}
\hline \multicolumn{5}{|c|}{ Correlations } \\
\hline \multirow{3}{*}{ GDP growth } & $\begin{array}{c}\text { Pearson Correlation } \\
\text { Sig. (2-tailed) } \\
\text { N }\end{array}$ & $\begin{array}{c}\text { GDP } \\
\text { growth }\end{array}$ & $\begin{array}{c}\text { FDI } \\
\text { growth }\end{array}$ & $\begin{array}{c}\text { EXP } \\
\text { growth }\end{array}$ \\
\hline \multirow{3}{*}{ FDI growth } & Pearson Correlation & 1 & & \\
& Sig. (2-tailed) & -.532 & 1 & \\
& $\mathrm{~N}$ & .075 & & \\
\hline \multirow{3}{*}{ EXP growth } & Pearson Correlation & .12 & 12 & \\
& Sig. (2-tailed) & .676 & .382 & 1 \\
& $\mathrm{~N}$ & 12 & 12 & 12 \\
\hline
\end{tabular}

Source: Author's calculation

As seen from the table above GDP ratio has a positive correlation with the export growth to .135 and sig. 676 . While a negative correlation with the increase of FDI -.532 , which means that any increase in this ratio affects the reduction of GDP growth.

\section{Econometric Model}

In order to assess how the variables will affect the model of GDP growth, we have adapted the model developed by the authors Batagli (2005) and Gurujati (2003), but adjusted to the circumstances in Macedonia. Linear regression model was used to determine the relative importance of each explanatory variable on the dependent variable. The value of the coefficient "p-value" of the explanatory variables to test the hypothesis is given as a model of significance level of $1 \%, 5 \%$ and $10 \%$. Linear regression model for GDP is as the following formula:

\section{Linear Regression Model}

Linear regression model for the growth of GDP is presented in the following equation. Based on the research conducted by the above mentioned authors on interconnection of foreign direct investments and the growth of GDP as a dependent variable, was assessed the impact of the explanatory variables on the economic growth of the country. In our concrete case, the aim of the research is to examine how foreign direct investments and the export growth will affect the economic growth. This study is based on the developed model of the authors Balasubramanyam (1996); Borensztin (1998); CAROVIC (2002) and Apergis (2008). This model was conducted using SPSS application software for econometrics.

Linear regression model for capital adequacy is: 


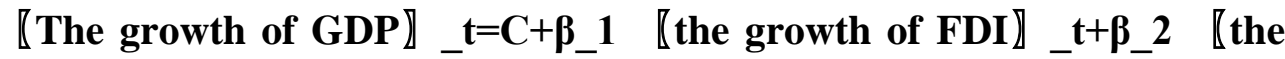 growth EXP】_t $+\varepsilon$}

Where:

The growth of GDP - Growth ratio of gross domestic product during the period $t$, The growth of FDI- The growth ratio of the foreign direct investments, The growth of EXP- The growth ratio of export as a $\%$ of GDP.

Where $\mathrm{t}=2014-2015, \mathrm{c}=$ constant for each Variable

In the table presented below is summarized a linear regression model where are shown the adjusted R, R2, R2, standard deviation and the DurbinWatson test.

Table 4. Model summary

\begin{tabular}{|c|c|c|c|c|c|}
\hline \multicolumn{7}{|c|}{ Model summary } \\
\hline Model & $\mathrm{R}$ & $\mathrm{R}^{2}$ & $\mathrm{R}^{2} \mathrm{i}$ adjusted & $\begin{array}{c}\text { The estimated } \\
\text { standard error }\end{array}$ & Durbin-Watson \\
\hline 1 & $.646^{\mathrm{a}}$ & .417 & .287 & .027425 & 2.139 \\
\hline \multicolumn{7}{|c|}{ a. Predictors: (Constant), the growth of EXP, the growth of FDI } \\
\hline \multicolumn{7}{|c|}{ b. Dependent Variable: the growth of GDP } \\
\hline
\end{tabular}

Source: Author's calculation

$\mathrm{R}$ is equal to .646a, where the dependent variable has a correlation 64.6 percent with the independent variables, while $\mathrm{R} 2$ is in the amount of .417 , which shows that 41.7 percent of the dependent variable is explained by the independent variables. R2 adjusted is in the amount of .287 , which shows that 28.7 percent of the variation in the dependent variable is explained by the variation of the independent variables. In order to verify the reliability of the model, within the analysis the serial correlation is used. The value of the correlation of the test Durbin-Watson may be in the range of 0 to 4.

If the value of the Durbin-Watson is close to zero, then the serial correlation indicates that the data in the model have a high positive influence between the residual values. If the correlation Durbin-Watson is offered to the value four (4) indicates that the data have a negative serial correlation. The model can be considered sustainable when the results of the DurbinWatson value are close to the interval of the value two (2). Durbin-Watson test is considered that there is no serial correlation within the range of 1.5 to 2.5 , which indicates that the residual value doesn t have a serial correlation or it does not exist an autocorrelation between the residual value.

Therefore, based on this interval, the findings in the study indicate that Durbin-Watson is of value 2.139, which is within the value interval, and shows that the model is stable. 
The results of linear regression Anova:

Table 5: The results of linear regression Anova

\begin{tabular}{|c|c|c|c|c|c|c|}
\hline \multicolumn{7}{|c|}{ ANOVA $^{\text {a }}$} \\
\hline \multicolumn{2}{|c|}{ Model } & Sum of Squares & Df & $\begin{array}{c}\text { Mean } \\
\text { Square }\end{array}$ & F & Sig. \\
\hline \multirow{3}{*}{1} & Regression & .005 & 2 & .002 & 3.217 & $.088^{\text {b }}$ \\
\cline { 2 - 7 } & Residual & .007 & 9 & .001 & & \\
\cline { 2 - 7 } & Total & .012 & 11 & & & \\
\hline \multicolumn{7}{|c|}{ a. Dependent Variable: Growth of GDP } \\
\hline \multicolumn{7}{|c|}{ b. Predictors: (Constant), growth of EXP, growth of FDI. } \\
\hline
\end{tabular}

Source: Author's calculation

F-test is equal to 0.88 and indicates that all together are statistically significant and different from zero.

\section{Linear regression coefficients}

Table 6: Linear regression coefficients

\begin{tabular}{|c|c|c|c|c|c|c|}
\hline \multicolumn{2}{|c|}{} & \multicolumn{6}{c|}{ Coefficients $^{\mathrm{a}}$} & \multirow{2}{*}{ S } & \\
\cline { 3 - 7 } & Model & \multicolumn{2}{c|}{$\begin{array}{c}\text { Std. } \\
\text { Error }\end{array}$} & Beta & \\
\hline \multirow{2}{*}{1} & B & .009 & & 6.705 & .000 \\
\cline { 2 - 6 } & $\begin{array}{c}\text { (Constants) } \\
\text { FDI } \\
\text { Growth }\end{array}$ & .030 & .012 & .683 & 2.481 & .035 \\
\cline { 2 - 6 } & $\begin{array}{c}\text { EXP } \\
\text { Growth }\end{array}$ & .031 & .022 & .396 & 2.438 & .044 \\
\hline \multicolumn{7}{|c|}{ a. Dependent Variable: GDP Growth } \\
\hline
\end{tabular}

Source: Author's calculation

Based on the given model and based on the calculation of coefficients through linear regression, the complete model with coefficients will be:

『The growth of GDP】_t=C+ $\beta_{-} 1$ 『The growth of FDI ${ }_{-} t+\beta_{-} 2$ 『The growth of EXP】_t $+\varepsilon$

The results presented in the table above indicate that the variable growth of FDI is positive with significance level of $97.9 \%$ with a positive sign $(\mathrm{P}=0.035)$. Econometric results show that $\%$ of FDI growth, generates $3.0 \%$ of growth in GDP, when all other factors of the model are held constant.

The econometric results show that export growth has a positive impact with a confidence level of $95.0 \%$ with a positive sign $(\mathrm{P}=0.044)$.

Econometric results show that $1 \%$ of export growth generates $10.3 \%$ of growth in GDP, when all other factors in the model are held constant. 


\section{Analysis and testing hypotheses}

In order to realize a quantitative research, most of the researchers are conducting research questionnaires. However, to provide research questions the submitted hypothesis should be realized. These hypotheses are the expectations achieved by the results, and they can be presented as alternative hypothesis specifying the precise outcomes. Also, the hypothesis can be presented as null or basic hypothesis, whose indications are based on it that, dependent variables will not be mutually connected, as pointed out by Creswell (2009). Therefore, our study was conducted based on the development of the following hypotheses:

Table 7: Summary of testing hypotheses

Source: Author's calculation

\begin{tabular}{|c|c|c|}
\hline $\begin{array}{l}\text { Submitted } \\
\text { hypothesis }\end{array}$ & $\begin{array}{c}\text { Confirmation with } \\
\text { YES / NO }\end{array}$ & Level of liability \\
\hline $\begin{array}{c}\text { H1: The ratio } \\
\text { FDI/GDP has a } \\
\text { positive impact on the } \\
\text { growth of the ratio } \\
\text { RRGDP }\end{array}$ & $\begin{array}{l}\text { Hypothesis has been } \\
\text { confirmed }\end{array}$ & $\mathrm{P}=0.035$ \\
\hline $\begin{array}{c}\text { H2: The ratio } \\
\text { EXP/GDP has a } \\
\text { positive impact on the } \\
\text { growth of the ratio } \\
\text { RRGDP }\end{array}$ & $\begin{array}{l}\text { Hypothesis has been } \\
\text { confirmed }\end{array}$ & $\mathrm{P}=0.044$ \\
\hline
\end{tabular}

\section{Conclusion and recommendations}

The competitive development of the Macedonian export sector will require investments in infrastructure, improving legislation and strengthening institutional capacity including:

- Investments in infrastructure

- Increased institutional efficiency

- Product standardization that will meet the requirements of international standards and the European Union.

The globalization process also has great influence towards the overall economic development of the countries. It has lead to greater development of the international markets, and will have further influence on the government policies that support the effective economic development.

The state governments and institutions for economic support should focus on increasing the volume of companies' production, the competitiveness and export promotion. The design and implementation of an integrated strategy for export promotion requires coordination of government activities, business associations and other stakeholders in some important areas. 
Foreign direct investments play a key role in the process of global economic integration. They are considered as a determinant of economic growth, starting from the micro level and ending up at the macro level, especially for developing countries, in which group also belongs the R. of Macedonia.

On the basis of the econometric analyze, which is based on linear regression we have reached conclusions regarding the position of export and foreign direct investments and their interconnection with other components that will affect the increase/decrease of the GDP. These conclusions are as follows:

- The econometric analysis shows that any increase in the ratio of foreign direct investments in relation to GDP, has a positive impact on the growth of gross domestic product, and it is certified with a confidence level of 97.00 percent, and also is verified in the given hypothesis.

- The econometric results given in the model show that any increase in the level of exports in relation to GDP, has a positive impact on the growth of gross domestic product, which is is also confirmed by econometric analysis with a confidence level of 95.0 percent.

\section{Recommendations}

Based on the empirical findings of this study, in addition are given some recommendations:

Macedonian authorities should implement the legal regulations that result from the commercial agreements, and from the tax system in accordance with the European Union legislation.

Therefore, the key sectors should be stimulated through specific policies and particular incentives in order to increase the interest of investors.

The unstable political environment increases the risk, which investors tend to avoid. In addition, political factors such as corruption, bureaucracy and lack of rule of law, are not the only risks, they also impose investments with additional direct cost.

\section{References:}

1. Benacek, V., Gronicki, M., Holland, D., Sass, M. The Determinants and Impact of Foreign Direct Investment in Central and Eastern Europe: A comparison of survey and econometric evidence, Transnational Corporations, Journal of United Nations, vol.9, no. 3, New York; (2000).

2. Bora, B. Foreign Direct Investment Research issues, Routledge, Taylor and Francis Group, London and New York; (2002). 
3. Hunya, G., Holzner, M., Wörz, J. How to assess the impact of FDI on an economy, Vienna Institute for International Economic Studies; (2003).

4. Jevcak, A., Setzer, R., Suardi, M. Determinants of Capital Flows to the New EU Member States before and during the Financial Crisis, European Commission, Economic Papers; (2010).

5. S. Lall, FDI and Development: Policy and Research Issues in the Emerging Context, Working Paper Number 43, Queen Elizabeth House, University of Oxford; (2000).

6. Neuhaus, M. The Impact of FDI on Economic Growth, An Analysis for the Transition Countries(2006).

7. Barrell, R. and Pain, N, Foreign Direct Investment, Technological Change, and Economic Growth Within Europe (1999),

8. Gurjati, D,Basic Econometrics, Fourth Edition. New York: The McGrow - Hill 2004

9. Report of Central Bank of Republic of Macedonia, 2013

10. Report of Central Bank of Republic of Macedonia, 2014

11. Report of Central Bank of Republic of Macedonia, 2015 